\title{
Retraction Note: Boundary behaviors for linear systems of subsolutions of the stationary Schrödinger equation
}

Zongcai Jiang ${ }^{1}$ and Francisco Marco Usó ${ }^{2 *}$

The original article can be found online at https://doi.org/10.1186/ s13660-016-1172-3

"Correspondence: f.marco.uso@gmail.com

2Department of Mathematics, University of Nigeria, Nsukka, 410001, Nigeria

Full list of author information is available at the end of the article

\section{Retraction Note}

The Editors-in-Chief have retracted this article because it shows evidence of peer review manipulation and authorship manipulation. In addition, the identity of the corresponding author could not be verified: the University of Nigeria, Nsukka has confirmed that Francisco Marco Uso has not been affiliated with their Department of Mathematics. The authors have not responded to correspondence regarding this retraction.

Author details

'School of Mathematics and Information Science, Henan University of Economics and Law, Zhengzhou, 450046, China. 2Department of Mathematics, University of Nigeria, Nsukka, 410001, Nigeria.

\section{Publisher's Note}

Springer Nature remains neutral with regard to jurisdictional claims in published maps and institutional affiliations.

Published online: 18 May 2021

\section{Springer}

(c) The Author(s) 2021. This article is licensed under a Creative Commons Attribution 4.0 International License, which permits use, sharing, adaptation, distribution and reproduction in any medium or format, as long as you give appropriate credit to the original author(s) and the source, provide a link to the Creative Commons licence, and indicate if changes were made. The images or other third party material in this article are included in the article's Creative Commons licence, unless indicated otherwise in a credit line to the material. If material is not included in the article's Creative Commons licence and your intended use is not permitted by statutory regulation or exceeds the permitted use, you will need to obtain permission directly from the copyright holder. To view a copy of this licence, visit http://creativecommons.org/licenses/by/4.0/. 